Journal of Patient-Centered

\title{
Health Care Transitions for Adolescents and Young Adults With Special Health Care Needs: Where Are We Now?
}

Nicole Mubanga

Dennis J. Baumgardner

Jessica J. F. Kram

Follow this and additional works at: https://aah.org/jpcrr

Part of the Health Services Administration Commons, Pediatrics Commons, and the Primary Care Commons

\section{Recommended Citation}

Mubanga N, Baumgardner DJ, Kram JJ. Health care transitions for adolescents and young adults with special health care needs: where are we now? J Patient Cent Res Rev. 2017;4:90-5. doi: 10.17294/ 2330-0698.1406

Published quarterly by Midwest-based health system Advocate Aurora Health and indexed in PubMed Central, the Journal of Patient-Centered Research and Reviews (JPCRR) is an open access, peer-reviewed medical journal focused on disseminating scholarly works devoted to improving patient-centered care practices, health outcomes, and the patient experience. 


\title{
Health Care Transitions for Adolescents and Young Adults With Special Health Care Needs: Where Are We Now?
}

\author{
Nicole Mubanga, MD, ${ }^{1}$ Dennis J. Baumgardner, MD, ${ }^{1,2,3}$ Jessica J. F. Kram, MPH ${ }^{1,2}$ \\ ${ }^{1}$ Department of Family Medicine, Aurora University of Wisconsin Medical Group, Aurora Health Care, Milwaukee, WI; \\ ${ }^{2}$ Center for Urban Population Health, Milwaukee, WI; ${ }^{3}$ Department of Family Medicine and Community Health, \\ University of Wisconsin School of Medicine and Public Health, Madison, WI
}

\begin{abstract}
Eventually, all adolescents must "graduate" from pediatric-oriented to adult-oriented health care. This transition, most often occurring during young adulthood, is especially important for adolescents with special health care needs and involves not only primary care physicians, but also both pediatric and adult subspecialists. Several studies support the benefit of transitional programs for adolescents and young adults with special health care needs. Additionally, the American Academy of Pediatrics named transitional care as one of its top priorities. However, transitional programs have yet to become an established norm among hospitals and providers, specifically outside of children's hospitals. This topic synopsis aims to draw attention to this important issue, review the rationale behind current recommendations and report the current status of transitional programs in North America. Moreover, the steps that individual clinicians, practices and health systems may take to plan for successful health care transitions are discussed. (J Patient Cent Res Rev. 2017;4:90-95.)
\end{abstract}

Keywords health care transition; pediatrics; adult care; adolescents; special health care needs; childhood-onset chronic disease

\section{What Is a Health Care Transition?}

As defined by the Society for Adolescent Medicine ${ }^{1}$ and reiterated recently by Fair and colleagues, ${ }^{2}$ a health care transition is "the movement of adolescents and young adults with chronic physical and medical conditions from child-centered to adult-oriented health care systems." It is a "complex and dynamic phenomenon" 3 that involves the skills, coordination and education of patients, families, clinicians and caregivers. ${ }^{4}$ Ultimately, each adolescent's health care transition journey is unique, ${ }^{3}$ predicted in part by various demographic, personal and ecological factors, in addition to the degree and specific features of disability. ${ }^{4,5}$

Correspondence: Dennis J. Baumgardner, MD, Aurora Sinai Medical Center, 1020 N. 12th Street, Milwaukee, WI, 53233, T: 414-219-5191, Email: dennis.baumgardner@aurora.org

\section{Why Are Health Care Transitions Important?}

In 1993, the Society for Adolescent Medicine "sounded the alarm" that high-quality health care transitions should be promoted. ${ }^{1}$ In 2002, Reiss and Gibson reported the need for systems change as well as personal/local education and activation to ensure effective transitions. ${ }^{3}$ That same year, a joint commission policy statement was issued by the American Academy of Pediatrics (AAP), American Academy of Family Physicians (AAFP) and the American College of Physicians (ACP)/Society of Internal Medicine regarding health care transition for young adults with special health care needs. ${ }^{6}$ For purposes of this review, we will generally center on a special needs population that was the focus of the consensus statement and described as "adolescents and young adults with severe medical conditions and disabilities that limit their ability to function and result in complicating social, emotional or behavioral sequelae." 6 
The joint commission's stated goal at that time was to ensure that by 2010 "all physicians who provide primary or subspecialty care to young people with special health care needs: 1) understand the rationale for transition from child-oriented to adult-oriented health care; 2) have the knowledge and skills to facilitate that process; and 3) know if, how and when transfer of care is indicated." ${ }^{\prime}$ The AAP annual leadership forum made transitioning youth with special health care needs to adult health care one of its top 10 priorities, and in 2011, the AAP, AAFP and ACP released an updated report that provided more specific guidance and further promoted health care transition for youth. ${ }^{7}$

Although transition is aimed to take place during young adulthood (ie, 18-21 years of age), it is recommended that transition planning begin around age 12 for all children and even earlier for children with special needs. ${ }^{6,8}$ Although pediatricians and pediatric subspecialists provide exceptional care to the pediatric patient, they are not trained in routine care of the adult patient. Certainly not all children with special needs (those with family medicine or internal medicine/ pediatric physicians and advanced practice providers) will need to transition their primary care clinician or medical home. However, even these patients are likely to encounter transition barriers to new adult specialists and facilities. ${ }^{5}$ Although many children's hospitals have transitional programs, they are not always effective; and a number of institutions, including even large pediatric practices, may not have transitional programs. ${ }^{9-11}$

Between age 12 and 18, there are yearly actions recommended — from simply discussing the clinic policy on transition to formulating a longitudinal plan with achievable goals - which ultimately lead to a well-organized transition plan in place prior to the youth turning 18 years old. ${ }^{7}$ This plan may be verbal if the patient has no chronic health conditions, or, particularly applicable for those with complex or special health care needs, it may be in the form of a written document that clearly identifies all providers involved in the transition of care, including primary care providers and both adult and pediatric subspecialists. The 2011 joint commission statement identified essential information needed by the receiving physician to ensure a smooth transition. Essential information includes the youth's baseline functional, neurologic and cognitive status (including any formal testing results), condition-specific emergency treatment plans and contacts, assessment of the patient's understanding of his or her condition, treatments and prognosis, procreation potential status and any genetic information. ${ }^{7}$

In turn, the receiving primary provider, whether internal medicine or family medicine, must be prepared to receive the adolescent or young adult patient. Responsibilities include identifying the legal health decision-maker and clearly discussing clinic policies with the patient and/ or family, including Health Insurance Portability and Accountability Act (HIPAA) regulations, particularly if the patient has become his or her own health care agent. The adult provider also should promote open communication with pediatric or adult subspecialty providers to prevent omissions or redundancies in care. ${ }^{7}$

\section{What Is the Status of Transitional Programs?}

Several reviews have identified worse health care outcomes among adolescents and young adults with special health care needs who did not transition appropriately. ${ }^{12-15}$ Other studies have evaluated the benefits of adequate health care transitions for these individuals. Benefits often associated with adequate transitions include reduced medical complications, improved patient-reported outcomes, greater adherence to care, positive patient experience and lower cost of health care. A study conducted by Annunziato et al demonstrated improved medication adherence in liver transplant patients who participated in a transitional program from 2007 to $2012 .{ }^{16}$

A few studies also demonstrated positive health, educational and vocational outcomes in youth with chronic illness, and higher levels of satisfaction and independence in patients with cystic fibrosis compared to peers without a transitional program. ${ }^{17,18}$ For example, successful transitional programs have been reported for patients with juvenile arthritis, type 1 diabetes and sickle cell disease. ${ }^{19-21}$

A recent Canadian study of 104,497 adolescents found that, at least in the short term, patterns of health care use and costs during transition did not differ appreciably from those prior to transfer. ${ }^{22}$ Additionally, McManus et al demonstrated that use of quality improvement techniques could affect systematic clinical transitions 
among adolescents in large pediatric practices in the district of Columbia. ${ }^{10}$

Nonetheless, formal transitional programs have had mixed success. ${ }^{23}$ A recent Cochrane review found limited quality studies that evaluated the effectiveness of specific interventions to improve adolescent transition from pediatric to adult health services, specifically for those with chronic conditions, and was unable to draw firm conclusions. ${ }^{24}$ Ultimately, "the field lacks a consistent and accepted way of measuring transition success, ${ }^{25}$ at least from a research standpoint.

Oswald and colleagues proposed the following clinical definition of successful transition: having the usual source of health care; having a provider who does not treat only children, adolescents and young adults; having insurance that meets the patient's needs; at least one preventive health visit in the past 12 months; satisfaction with health care services; and no delayed or foregone needed health service in the past 12 months. ${ }^{13}$

Certainly, "health care transition planning is not occurring as a standard of care."11 It is our own experience that many adult providers are reluctant to receive young adults with special needs due to case complexity, length of office visits and perceptions about expectations regarding their own comfort and expertise. Indeed, similar transition issues were expressed by internal and family medicine providers responding to surveys. ${ }^{26,27}$

\section{Why Have Health Care Transitions Not Become an Efficient Standard of Care?}

This is a fair question, particularly in the era of integrated medical organizations and electronic medical records. Even within the same institution with a common information system, successful transition from pediatric to adult specialty services may be limited for a large number of individuals. ${ }^{28}$ Several potential barriers to widespread implementation have been identified, particularly among receiving adult providers. These barriers include deficits in education and/or experience.

A nationwide survey conducted by Okumura et al demonstrated a significant lack of comfort in providing primary care for young adults with special care needs (specifically cystic fibrosis and sickle cell disease), with only $15 \%-38 \%$ of respondents feeling comfortable being the primary care provider. ${ }^{29}$ Other barriers to providing adult primary care to youth with special needs is lack of training in congenital and childhood illnesses, lack of time and lack of reimbursement for time to coordinate care. ${ }^{11,13,21,26,30}$ No doubt, low volumes of transitioning special needs young adults in most medical practices (and each patient's unique set of issues) contribute to providers' perception or actuality of failing to keep current with proper treatment of these individuals.

In addition to the logistic, bureaucratic, medical information and communication challenges in transitioning to adult health services, there are also medical, intellectual, behavioral and emotional issues among adolescents that must be acknowledged. ${ }^{5,11,31}$ This includes the loss of relationships with previous clinicians and staff (pediatric providers may have difficulty letting go as well), ${ }^{3}$ and the increased emphasis on autonomy and responsibility of the patient, which the adolescent may not be developmentally capable of assuming. ${ }^{31,32}$

A survey of 183 parents and guardians of youth with autism spectrum disorders revealed that only $60 \%$ received transition services, despite high rates of insured status and access to health care. ${ }^{33}$ The greatest impediments in this population included reported lack of information regarding the transition process and difficulty finding an adult primary care clinician with sufficient knowledge of autism spectrum disorder. ${ }^{33}$ A convenience sample survey of 155 transitioning patients with various childhood chronic diseases and 104 parents reported that significant gaps in transition education existed regarding a variety of health-related and future vocational issues. ${ }^{32}$ This report also cited lack of adult specialist providers as a barrier to transition. ${ }^{32}$

Perhaps most illustrative were detailed stories of patients' and parents' experience with the transition process. Three such examples illustrated significant time delays, emotional and practical issues of being made to leave one group of providers for another, the simultaneous occurrence of educational, vocational, transportation and insurance changes, and diminution of parental input at medical visits. ${ }^{34}$ Patients and family/ guardian caregivers themselves may present additional 
barriers. Their level of health literacy, adherence to plans, and a variety of cultural, environmental, demographic and systemic variables may affect health care transition preparation and success. ${ }^{11}$ Indeed, as Hergenroeder et al noted: "It is important to distinguish between health care transition eligibility and readiness."

Finally, the patient's school system is vitally important in health care transitions. Data suggests that transition planning occurs for a majority of students, but that the students themselves may have limited opportunity to lead planning sessions; other contributors, such as vocational agencies, may be limited..$^{35}$ Anecdotally, school systems appear to vary in their quality of contribution toward health care transition, and communication with the medical home is often lacking.

\section{Where Do We Go From Here in Our Own Practices?}

It is clear that a smooth, seamless health care transition from pediatric to adult primary care providers is desired for all youth but is particularly important for youth with special health care needs. Pediatricians, internists, family physicians and subspecialists all have unique roles within the medical home model, and open, ongoing communication among these providers is essential to providing continuous care. The transition may be conducted between individual providers through an established care transition plan within a group or system. Transition also may occur through a dedicated clinic serving as a bridge between adult and pediatric primary care, which may ease the transition to adult providers who otherwise may be uncomfortable with the intricacies of transitional planning and care of youth with special health care needs, particularly if not a regular part of their clinical practice.

It is important that formal "hand-offs" occur between pediatric and adult medical homes and specialists. ${ }^{5}$ Eager and willing acceptance of transitioning patients by adult-oriented providers is essential. One potential decision point is whether pediatric subspecialists should assume the role of choosing and partnering with adult care specialists or whether that should be the responsibility of the primary care clinician. We favor the latter, as primary care consists of the individuals who receive specialist reports, refer for future specialist care and, in many cases, are in a better position to ensure the receiving specialist is covered by the patient's health insurance.

With a longer life expectancy for children with congenital and other chronic health care conditions, ${ }^{31,36}$ adult medicine provider training will likely need to evolve to include pediatric illnesses among adult patients. Another potential solution involves pediatric subspecialists continuing to care for young adults in certain situations of pediatric diseases that extend into adulthood. ${ }^{5}$

It is most important to ensure that one's own medical practice has a transition policy and a transition registry or database. ${ }^{9}$ Preferably there is a general health care transition plan for the entire practice and a specific one for each transitioning individual. Start early, no later than between the ages of 12 and $14 .{ }^{9}$ Such plans should include more patient-centered outcomes like quality of life. ${ }^{2}$ Guidelines and resources are available for statelevel, community-level and practice-level assistance in transition care (and for areas of future research). .,25,37,38

Fifteen years ago, Reiss and Gibson listed factors associated with apparently successful transitions based on the results of a series of focus groups involving youth and young adult patients, families and caregivers. ${ }^{3}$ This list is useful yet today as a starting point for health care transition plans and includes: 1) patient, family and medical providers having a future focus; 2) early start to transition; 3) fostering as much personal and medical independence by the patient as is possible; 4) including future planning for insurance, equipment and navigation skills in addition to future providers; 5) the transitioning patient vocalizing the desire to "function in the adult medical world;" 6) ensuring service reimbursement is not interrupted; 7) pediatric clinicians continuing to provide some care into adulthood; and 8) the patient continuing to receive services from the same health care system. ${ }^{3}$

Parents, family and guardians should continue to be included in transition planning. They are critical and often the main determinants of transition success or failure. It is important to remember - and have sensitivity regarding - the significant stress experienced by family caregivers of patients with disabilities, particularly at a time of transition. ${ }^{39}$ Additionally, due to the variability 
in the comprehensiveness of transition information given to parents of special needs adolescents, medical homes may need to supplement a family's knowledge base regarding certain critical nonmedical issues. For example, in the state of Wisconsin, parental guardianship is not assumed when the patient reaches age 18 , and proactive legal consultation is necessary. ${ }^{40}$

\section{Conclusions}

For practical assistance, several sources cited herein have useful checklists to guide patients, families and medical homes in the transition process. ${ }^{8,931,38}$ Moreover, we encourage their use. The article by Hergenroeder et al may be consulted for a robust discussion of current issues in transition beyond the scope of this brief review. ${ }^{11}$ The "Got Transition" project is especially recommended as a standard-of-care source for further information. ${ }^{38}$

By staying cognizant of specialized needs, using the available tools and, perhaps most importantly, maintaining a willingness to deviate from daily clinical routine, all caregivers can do their part to improve health care transitions for youth with physical and intellectual disabilities.

\section{Patient-Friendly Recap}

- A health care transition occurs when an adolescent or young adult changes from pediatric to adult care.

- Health care transitions in youth with physical and mental disabilities can prove challenging and be unsuccessful if not properly planned by patient (when possible), family and clinicians.

- The authors comment on the current lack of standardized transition planning in those with special health care needs and detail the essential components of adequate transition, emphasizing an early start to planning as well as continued involvement of all parties connected to the patient's care.

\section{Acknowledgments}

The authors wish to thank four anonymous peer reviewers who provided significant input into the initial submission, which was prepared by first author Nicole Mubanga.

\section{Conflicts of Interest}

None.

\section{References}

1. Blum RW, Garell D, Hodgman $\mathrm{CH}$, et al. Transition from child-centered to adult health-care systems for adolescents with chronic conditions. A position paper of the Society for Adolescent Medicine. J Adolesc Health. 1993;14:570-6. CrossRef

2. Fair C, Cuttance J, Sharma N, et al. International and interdisciplinary identification of health care transition outcomes. JAMA Pediatr. 2016;170:205-11. CrossRef

3. Reiss J, Gibson R. Health care transition: destinations unknown. Pediatrics. 2002;110:1307-14.

4. Javalkar K, Johnson M, Kshirsagar AV, Ocegueda S, Detwiler RK, Ferris M. Ecological factors predict transition readiness/ self-management in youth with chronic conditions. J Adolesc Health. 2016;58:40-6. CrossRef

5. Schor EL. Transition: changing old habits. Pediatrics. 2015;135:958-60. CrossRef

6. American Adademy of Pediatrics; American Academy of Family Physicians; American College of Physicians/American Society of Internal Medicine. A consensus statement on health care transitions for young adults with special health care needs. Pediatrics. 2002;110:1304-6.

7. American Academy of Pediatrics; American Academy of Family Physicians; American College of Physicians; Transitions Clinical Report Authoring Group, Cooley WC, Sagerman PJ. Supporting the health care transition from adolescence to adulthood in the medical home. Pediatrics. 2011;128:182-200. CrossRef

8. Wisconsin Community of Practice on Transition Practice Group on Health. Transition health care checklist: preparing for life as an adult. http://www.waisman.wisc.edu/cedd/pdfs/ products/health/THCL.pdf. Accessed May 20, 2016.

9. Lemly DC, Weitzman ER, O'Hare K. Advancing healthcare transitions in the medical home: tools for providers, families and adolescents with special healthcare needs. Curr Opin Pediatr. 2013;25:439-46. CrossRef

10. McManus M, White P, Barbour A, et al. Pediatric to adult transition: a quality improvement model for primary care. J Adolesc Health. 2015;56:73-8. CrossRef

11. Hergenroeder AC, Wiemann CM, Cohen MB. Current issues in transitioning from pediatric to adult-based care for youth with chronic health care needs. J Pediatr. 2015;167:1196-201. CrossRef

12. Sable C, Foster E, Uzark K, et al. Best practices in managing transition to adulthood for adolescents with congenital heart disease: the transition process and medical and psychosocial issues: a scientific statement from the American Heart Association. Circulation. 2011;123:1454-85. CrossRef

13. Oswald DP, Gilles DL, Cannady MS, Wenzel DB, Willis $\mathrm{JH}$, Bodurtha JN. Youth with special health care needs: transition to adult health care services. Matern Child Health J. 2013;17:1744-52. $\underline{\text { CrossRef }}$

14. Committee on Improving the Health, Safety, and Well-Being of Young Adults; Board on Children, Youth, and Families; Institute of Medicine; National Research Council; Bonnie RJ, Stroud C, Breiner H (eds). Investing in the health and wellbeing of young adults. Washington, DC: National Academies Press, 2015. 
15. Monaghan M, Hilliard M, Sweenie R, Riekert K. Transition readiness in adolescents and emerging adults with diabetes: the role of patient-provider communication. Curr Diab Rep. 2013;13:900-8. CrossRef

16. Annunziato RA, Baisley MC, Arrato N, et al. Strangers headed to a strange land? A pilot study of using a transition coordinator to improve transfer from pediatric to adult services. J Pediatr. 2013;163:1628-33. CrossRef

17. Chaudhry SR, Keaton M, Nasr SZ. Evaluation of a cystic fibrosis transition program from pediatric to adult care. Pediatr Pulmonol. 2013;48:658-65. CrossRef

18. Maslow G, Adams C, Willis M, et al. An evaluation of a positive youth development program for adolescents with chronic illness. J Adolesc Health. 2013;52:179-85. CrossRef

19. McDonagh JE, Southwood TR, Shaw KL; British Society of Paediatric and Adolescent Rheumatology. The impact of a coordinated transitional care programme on adolescents with juvenile idiopathic arthritis. Rheumatology (Oxford). 2007;46:161-8. CrossRef

20. Holmes-Walker DJ, Llewellyn AC, Farrell K. A transition care programme which improves diabetes control and reduces hospital admission rates in young adults with Type 1 diabetes aged 15-25 years. Diabet Med. 2007;24:764-9. CrossRef

21. Treadwell M, Telfair J, Gibson RW, Johnson S, Osunkwo I. Transition from pediatric to adult care in sickle cell disease: establishing evidence-based practice and directions for research. Am J Hematol. 2011;86:116-20. CrossRef

22. Cohen E, Gandhi S, Toulany A, et al. Health care use during transfer to adult care among youth with chronic conditions. Pediatrics. 2016;137:e20152734. CrossRef

23. Lindsay S, Cruickshank H, McPherson AC, Maxwell J. Implementation of an inter-agency transition model for youth with spina bifida. Child Care Health Dev. 2016;42:203-12. CrossRef

24. Campbell F, Biggs K, Aldiss SK, et al. Transition of care for adolescents from paediatric services to adult health services. Cochrane Database Syst Rev. 2016;4:CD009794. CrossRef

25. McPheeters M, Davis AM, Taylor JL, Brown RF, Potter SA, Epstein RA Jr. Transition care for children with special health needs [Internet]. Report No.: 14-EHC027-EF. AHRQ Comparative Effectiveness Technical Briefs. Rockville, MD: Agency for Healthcare Research and Quality, 2014.

26. Peter NG, Forke CM, Ginsburg KR, Schwarz DF. Transition from pediatric to adult care: internists' perspectives. Pediatrics. 2009;123:417-23. CrossRef

27. McLaughlin SE, Machan J, Fournier P, Chang T, Even K, Sadof M. Transition of adolescents with chronic health conditions to adult primary care: factors associated with physician acceptance. J Pediatr Rehabil Med. 2014;7:63-70. $\underline{\text { CrossRef }}$
28. Bohun CM, Woods $\mathrm{P}$, Winter $\mathrm{C}$, et al. Challenges of intrainstitutional transfer of care from paediatric to adult congenital cardiology: the need for retention as well as transition. Cardiol Young. 2016;26:327-33. CrossRef

29. Okumura MJ, Heisler M, Davis MM, Cabana MD, Demonner S, Kerr EA. Comfort of general internists and general pediatricians in providing care for young adults with chronic illnesses of childhood. J Gen Intern Med. 2008;23:1621-7. CrossRef

30. Tuchman LK, Schwartz LA, Sawicki GS, Britto MT. Cystic fibrosis and transition to adult medical care. Pediatrics. 2010;125:566-73. CrossRef

31. Abell RL, Winter M, Kreipe RE. Transition from pediatric to adult centered care: lessons from the literature and the trenches. Adolesc Med State Art Rev. 2016:27:193-208.

32. Fernandes SM, O'Sullivan-Oliveira J, Landzberg MJ, et al. Transition and transfer of adolescents and young adults with pediatric onset chronic disease: the patient and parent perspective. J Pediatr Rehabil Med. 2014;7:43-51. CrossRef

33. Kuhlthau KA, Delahaye J, Erickson-Warfield M, Shui A, Crossman M, van der Weerd E. Health care transition services for youth with autism spectrum disorders: perspectives of caregivers. Pediatrics. 2016;137 Suppl 2:S158-66. CrossRef

34. Hopper A, Dokken D, Ahmann E. Transitioning from pediatric to adult health care: the experience of patients and families. Pediatr Nurs. 2014;40:249-52.

35. Shogren KA, Plotner AJ. Transition planning for students with intellectual disability, autism, or other disabilities: data from the National Longitudinal Transition Study-2. Intellect Dev Disabil. 2012;50:16-30. CrossRef

36. Zhao JY, Chiu PP, Dasgupta R, Jen HC, Rothstein DH. Defining the need for transitional care from pediatric to adult surgery for young adult patients with surgically corrected congenital anomalies. JAMA Surg. 2016;151:393-4. CrossRef

37. Stewart D. Transition to adult services for young people with disabilities: current evidence to guide future research. Dev Med Child Neurol. 2009;51 Suppl 4:169-73. CrossRef

38. The National Alliance to Advance Adolescent Health. Got Transition/Center for Health Care Transition Improvement home page. www.gottransition.org/. Accessed January 25, 2017.

39. Chambers HG, Chambers JA. Effects of caregiving on the families of children and adults with disabilities. Phys Med Rehabil Clin N Am. 2015;26:1-19. CrossRef

40. Understanding Guardianships: A Handbook for Guardians, 10th Edition. Madison, WI: State Bar of Wisconsin, 2010.

(C) 2017 Aurora Health Care, Inc. 